Editorial

\title{
Forage Plant Ecophysiology: A Discipline Come of Age
}

\author{
Cory Matthew ${ }^{1, *}$ and Lilian Elgalise Techio Pereira ${ }^{2}$ \\ 1 Institute of Agriculture and Environment PN 433, Massey University, Private Bag 11-222, \\ Palmerston North 4442, New Zealand \\ 2 Animal Science Department, University of São Paulo, Faculdade de Zootecnia e Engenharia de Alimentos, \\ Av. Duque de Caxias Norte, 225, Pirassununga CEP 13635-900, Brazil; ltechio@yahoo.com.br \\ * Correspondence: c.matthew@massey.ac.nz; Tel.: +64-6-356-9099 (ext. 84802); Fax: +64-6-350-5679
}

Received: 17 July 2017; Accepted: 24 July 2017; Published: 27 July 2017

\section{Introduction}

The first use of the term "ecology" is credited to German scientist Ernst Haekel in 1866, who used the word to describe the total science of relationships between organisms and their environment [1]. Over time, the complexity of organism-environment interactions has led to the definition of specialist fields within the wider discipline of ecology, one of those being 'ecophysiology'. The dictionary definition of ecophysiology is, "the science of the relationships between the physiology of organisms and their environment" [2]. The first use of the term 'ecophysiology' known to the authors was in 1956, by a French entomologist employed by L'Institut National de la Recherche Agronomique (INRA), Remy Chauvin [3]. Credit for forward thinking should be given to the staff of INRA, who in the mid-1980s established a centre at Lusignan initially known as the Station d'Ecophysiologie des Plantes Fourragères (SEPF), and later as the Unité d'Ecophysiologie des Plantes Fourragères (UEPF). In 2008, the UEPF was incorporated into the Unité de Recherche Pluridiciplinaire Prairies et Plantes Fourragères (URP3F) [4].

From those beginnings, ecophysiology is now an internationally recognised branch of ecology, as indicated by recent publication of an editorial entitled 'Focus on Ecophysiology' in a major scientific journal [5]. Here we more specifically focus on 'forage plant ecophysiology'. The ability of plants to cope with a wide range of abiotic constraints (including but not limited to drought, salinity, heat, freezing, wind, flooding, and soil acidity) and biotic challenges faced in the diverse physiographic landscapes around the world is fascinating. From a scientific perspective, forage plant ecophysiology is a fertile ground for the study of plant physiology in action. More than that, the discipline is set to become increasingly important for the development of sustainable food production systems in a world experiencing increasing human population pressure and environmental change resulting from human perturbation of various longstanding global equilibria.

For our purposes, forage plant ecophysiology includes the consideration of the tactical significance of a plant body plan [6] in competitive interaction with other plants or as a contributing factor to plant performance, as well as how the plant body plan and metabolic processes combine to capture nutrients, water, and light, ultimately contributing to survival. By definition, forage plant ecophysiology also encompasses considerations that arise from the use of plants as food for animals (including the impact on nutritive value) and of plant responses to grazing management and agronomic practices (for example, fertiliser regimes). Similarly, the forage plant ecophysiologist may find that stakeholders expect the work to extend to investigating the optimisation of resource use and farm system outputs. In compiling this volume, we sought contributions from each continent of the world, representative of the major forage species in each region. Inevitably, the contributions received are only a representative sample of the diversity of work currently in progress worldwide, and in this synopsis of the contributions, some of the more major gaps are acknowledged by the citation of relevant research external to this special issue. 


\section{Studies of Forage Legumes and Forage Herbs}

Contributions to this volume include studies of Medicago sativa L., of interspecific hybrids between Trifolium repens $\mathrm{L}$. and Trifolium ambiguum M. Bieb., and of Lotus corniculatus L., in addition to the nutritional benefits to ruminants of secondary metabolites present in L. corniculatus herbage.

One of the most significant forage plant species in world agriculture is M. sativa, known as alfalfa in the United States and as lucerne in Britain and Europe. Its deep taproot and nitrogen fixing ability as a member of the legume family make it a versatile plant for a range of arid environments. Alfalfa produces forage with comparatively high protein levels. A review of the Web of Science database reveals over 15,000 published articles with alfalfa or lucerne in the title. However, despite this large volume of prior research, there are no data on the effect of salinity on the antioxidant capacity of alfalfa [7]. Salinity stress induces an ionic imbalance, which results in osmotic stress, usually followed by ionic toxicity and the generation of higher levels of reactive oxygen species (ROS) than are normal in unstressed plants. To neutralise ROS and protect plant tissues, non-enzymatic and enzymatic antioxidants are produced. Although the importance and expression of a number of antioxidant enzymes have been identified, the biosynthesis of non-enzymatic antioxidants, such as flavonoids and phenolic compounds, has been much less studied. In this volume [7], it is shown that alfalfa cultivars, previously tested for salinity tolerance, were well able to maintain their total antioxidant capacity represented by shoot content of flavonoids and phenolic compounds when irrigated with saline water containing up to $169 \mathrm{mM} \mathrm{L}^{-1} \mathrm{Na}^{+}$(electrical conductivity $18.4 \mathrm{dS} . \mathrm{m}^{-1}$ ). This study also investigated the effect of salinity on forage mineral levels and forage quality. Salinity significantly increased shoot $\mathrm{N}, \mathrm{P}, \mathrm{Mg}$, and S, but decreased Ca and $\mathrm{K}$. Salinity also slightly improved forage nutritive value by significantly increasing crude protein [7].

White clover (T. repens) is another forage legume of great significance in world agriculture, and a very widely used companion legume to sown grasses in temperate pastures [8] with rainfall $>700 \mathrm{~mm} \mathrm{year}^{-1}$. White clover is now known to be an allotetraploid $(2 n=4 x=32)$ with progenitor species Trifolium occidentale Coombe and Trifolium pallescens Schreb [9]. Both because of expected increase in incidence of drought through changing climatic conditions, as well as from an interest in extending the range of white clover, techniques have been developed for the introgression of genes into white clover from the more strongly rooted and drought resistant T. ambiguum (Caucasian clover), through interspecific hybridisation and backcrossing. The backcrosses were found to exhibit root characteristics intermediate between the parents with better tissue hydration in drought (evidenced by less negative osmotic potential), but with reduced stolon growth, compared to white clover parent plants [8]. Further research is needed to clarify whether these hybrid plants combining the productivity traits of white clover with the improved drought resistance from introgression with Caucasian clover germplasm will maintain these characteristics in older swards as the plants age.

Two other forage legumes that have attracted significant research interest, not least because their foliage contains condensed tannins (CT), are Lotus corniculatus L. (birdsfoot trefoil) and Onobrychis viciifolia Scop (sainfoin). CT can chemically bind with dietary protein, leading to a 'rumen bypass' effect, reducing enteric methane emissions and increasing the quantity of protein that is absorbed from the intestines [10]. L. corniculatus is well-adapted to cultivation under irrigation in climates with warmer summers, colder winters, and alkaline soils found in the Intermountain West region of the USA. In this volume, performance data for animals fed grass or concentrate diets are compared with those for animals fed birdsfoot trefoil. Of note are findings that, for animals whose diet comprised birdsfoot trefoil, carcass dressing out $\%$ at slaughter was increased, and meat flavour score in a taste panel test was enhanced compared to the results for animals fed grass, and comparable to the results for animals fed mixed ration diets [10].

Two forage herbs now widely used as special purpose feeds in temperate pastoral systems which help farmers increase the energy intake of animals (e.g., for pre-slaughter weight gain or for late pregnancy and early lactation feed for muliparous ewes) are Cichorium intybus L. (Chicory) and Plantago lanceolata L. (Plantain). While we did not manage to secure a contribution on these 
species, there is a growing body of information on the agronomy, physiology, and animal performance expectations for these crops [11-14]. Other forage herbs are also potentially valuable. For example, Sanguisorba minor Scop. (salad burnet) is of interest to reduce urinary nitrogen concentration and enteric methane emissions.

\section{Studies of Forage Grasses}

The first contribution in this section explores the seasonal dynamics of root formation in Lolium perenne L. (perennial ryegrass) [15]. While the coordination of the developmental processes between modules of the shoot and the way they interact to define tiller axis structure and growth are now well described $[16,17]$, knowledge of the growth processes regarding belowground organs and their integration with shoot development is still rudimentary. Here it is established from data on root ingrowth to refilled cores that root mass deposition is typically about $15 \%$ of the aboveground herbage dry matter accumulation, with seasonal periods of root formation activity typically preceding shoot activity by a few weeks [15]. The field data presented support a previously published hypothesis [18] that plant architecture, through the delay between leaf and root formation at a given phytomer, does provide a mechanism to increase root growth in early summer and decrease it in early winter [15]. Furthermore, a novel functional ecology insight emerges that the cessation of new root production in summer dry conditions [19] allows for the supply of photosynthetic substrate, which would have been captured by the newly formed young roots, to continue to reach older roots and so allow those roots to penetrate deeper in summer dry conditions than at times when surface soil layers have available water [15].

The second contribution in this section, assuming that tissue deposition processes in different parts of a plant are in competition, effectively explores the impact on other plant structures of a change in plant body plan towards increased rhizome production in Schedonorus arundinaceus (Schreb.) Dumort (tall fescue) [20]. Surprisingly, biomass allocation to rhizomes did not differ statistically between the rhizomatous and non-rhizomatous populations studied (although it was markedly reduced by defoliation in both populations). However, it was visually obvious that rhizome formation in the rhizomatous population was accounted for by a subtle shift in distribution of internode length, with a few longer internode segments typically located on secondary and tertiary tillers in the rhizomatous plants. Rhizomatous tall fescue plants had a longer interval between the appearance of successive leaves, an increased rate of tiller bud site filling to compensate for the reduced number of bud sites, and longer, narrower leaves than the non-rhizomatous population. However, this is felt to reflect the adaptation to infrequent and frequent defoliation, respectively, in the two populations, and is not thought to be a direct consequence of rhizomatous or non-rhizomatous growth habits [20]. The rhizomatous population displayed increased biomass allocation to root and decreased biomass allocation to pseudostem compared to the non-rhizomatous population, but the functional significance of this is not clear [20].

In contrast with temperate pastures, where there has already been a comprehensive body of research in place for 30 years [16], reports on the systematic study of tropical or subtropical grass swards have begun to appear in the English literature only within the last decade [21,22], and at present there are comparatively few studies, although they include some fine work on rangeland species of the USA [23] and earlier work in Portuguese does need to be acknowledged [24]. Accordingly, one contribution in this volume [25] seeks to review the state of knowledge relating to sward dynamics of tropical grass species, with particular reference to the genera Brachiaria, Pennisetum, and Panicum (tussock forming grasses), as well as Cynodon dactylon (L.) Pers. (a species with a creeping habit spreading by stolons and rhizomes). The authors systematically compare the key principles of sward dynamics in temperate and tropical pastures, and identify common factors and points of difference. Although tropical grasses have the $C_{4}$ photosynthesis pathway whereas temperate species are $C_{3}$ plants, this does not in itself confer behavioural difference. Rather, the sward dynamics of competition for light at higher light levels in the tropics appear to define the greatest points of difference between 
temperate and tropical grasses. In making this point, the authors contrast their grazing optimisation theory with earlier approaches based on defining the herbage regrowth curve. Compared to temperate pastures, tropical grass swards have large numbers of aerial tillers (which can be assumed to contribute to rapid leaf area recovery in early regrowth) and are prone to vegetative stem elongation at canopy closure. Hence, infrequent defoliation maximises herbage dry matter production but at a cost to sward quality; conversely, more frequent defoliation delivers reduced dry matter yield but a higher proportion of dry matter production as leaf [25]. Principles of tiller size density compensation [26] are confirmed to apply to both temperate and tropical swards, but the larger tillered tropical grasses tend to be tussock-forming with a size density compensation able to occur both in terms of size and density of tussocks and of tiller size within tussocks. Despite these generalisations, the authors note a very wide variation in morphology and behaviour among the tropical grass species [25].

The creeping tropical grasses such as Cynodon are hypothesised to represent an alternative strategy for light capture, whereby according to area:volume theory, clonal integration reduces the need for stem development [25]. They also note that, whereas major temperate grasses tend to have a single elongating and senescing leaf at any one time, tropical grasses tend to have at least two elongating leaves for every senescing leaf, and that leaf senescence rates $\left(\mathrm{mm} \mathrm{day}^{-1}\right)$ are very high in steady state leaf turnover approaching canopy closure. As a point for future research, a generally higher leaf appearance rate and leaf elongation rate for younger tillers compared to that for older tillers are often reported in tropical grasses, which may mean that grazing management could be manipulated to obtain a favourable mix of tiller age classes [25].

Given the very large areas of Pennisetum clandestinum Hochst. ex. Chiov. (kikuyu grass) pasture that exist in many subtropical regions of the world, it was a regret that we did not secure a contribution dealing with that species. A key point about kikuyu is that, in areas too warm for temperate grasses such as L. perenne to thrive, it can be used as the primary sown species to support intensive pastoral production systems [27], though it is also comparatively tolerant of lower soil fertility.

The self-thinning principle [28], also seen as defining constant leaf area sward status at different defoliation heights, while other factors remain unchanged [26], was used in the next contribution. This principle was applied in a reverse density:weight format to model the tiller density of Paspalum notatum Flüggé (bahiagrass) swards at different grazing heights [29]. The model simulates changes in tiller density by calculating tiller appearance and death rates from input variables defining sward status, environmental factors (annual $\mathrm{N}$ fertilizer application, temperature, season), and management. The calculated birth and death rates are then applied as increments to the current population. A driver of the model is the ratio of expected:actual tiller density, which acts to increase site filling and relative tiller appearance when the tiller density is lower than expected. Meanwhile, tiller death rate is controlled by factors such as air temperature and season. In validation studies, the model closely predicted measured tiller density ranges of 2000 to 6000 tillers per $\mathrm{m}^{2}$ in response to cutting height ranges from 22 to $2 \mathrm{~cm}$, respectively, but did not always predict observed falls in tiller density. The author suggests that linking the ratio of expected:actual tiller density to tiller death as well as tiller birth rates may improve model performance [29]. However, the fact that the emerging understanding of sward dynamics principles can be applied to achieve credible predictions of grass sward tiller density is indicative that theory in this discipline is engaging with reality.

A very interesting contribution in this section [30] comprehensively analyses the possibility of improving herbage performance in perennial forage grasses by breeding for a defined leaf length. The authors show that the survival of short-leaf genotypes in a mixture with long-leaf types is lower under infrequent compared to frequent cutting, indicating that the ideal leaf length may be dependent on management regime. The authors point out the complexity of plant factors that determine the realised length of a given leaf. Such factors may be environmental, acting through the modification of factors such as leaf elongation rate and duration, or they may be architectural, acting through the effect of factors such as sheath length on the timing of initiation and the cessation of cell division during leaf elongation. They suggest that many measurements of leaf length may be biased by these factors 
and not represent the true genetics of the plant. They further note that leaf length is controlled by a large number of genes, each acting incrementally and cumulatively with others, so that breeding for a desired target will not be straightforward. In discussing the identification of quantitative trait loci (QTL) linked to leaf length, they propose that morphogenetic modelling to separate leaf microenvironment or architectural effects from genetic effects on leaf length, coupled with wider screening for genes affecting leaf length, might lead to the identification of 'more consistent QTL' [30].

A topic that has engaged agronomy researchers for decades is the possibility of defining grazing management targets for maximal herbage production. With particular focus on temperate dairy pasture management, the last contribution in this section explores how an analysis of pasture regrowth curves might inform grazing management. In the scenario presented, the avoidance of reduced herbage accumulation through grazing too leniently and incurring leaf senescence at the end of the regrowth interval, and of over-grazing and incurring a delay in the recovery of leaf elongation, while at the same time choosing a defoliation interval to maximise average growth rate for the optimal defoliation intensity, will theoretically increase herbage harvested compared with any alternative grazing management regime. It is acknowledged that considerations of optimising nutritive value, of sward persistence, or of using grazing management to control animal intake may override those of residual herbage mass and defoliation interval effects on mean herbage accumulation rate, but it is pointed out that in current New Zealand farm practice, a majority of grazing events occur earlier in the regrowth cycle than appears to be optimal according to the presented theoretical example [31].

\section{Plant Physical and Physiological Systems}

A less explored branch of ecophysiology is the link between plant morphology and plant performance. Nowhere is this link more evident than in the variety of morphological patterns seen in the seeds of different species to facilitate the eventual establishment of a young plant following germination. This rather underdeveloped field has been for some years the specialty of a group of Chinese researchers [32]. In this volume, members of that team use parameters of a thermal time model to compare germination temperature and strategies of $15 C_{3}$ and $12 C_{4}$ species comprised of a mixture of annuals and perennials with a range of seed mass values [33]. They found that neither the base temperature for germination, $T_{\mathrm{b}}$, nor the thermal time constant, $\theta_{1}$, was correlated with seed mass, but $T_{\mathrm{b}}$ of $\mathrm{C}_{3}$ species was typically approximately $5^{\circ} \mathrm{C}$ while $\theta_{1}$ ranged from $9-63^{\circ} \mathrm{C} \cdot \mathrm{d}$. In comparison, $T_{\mathrm{b}}$, of the $\mathrm{C}_{4}$ species ranged from $-3.6{ }^{\circ} \mathrm{C}$ to $11.6{ }^{\circ} \mathrm{C}$ while $\theta_{1}$ for those species ranged from $5-23^{\circ} \mathrm{C} \cdot \mathrm{d}$, with the parameters for particular species reflecting its life cycle characteristics.

The way plant physiological processes in winter wheat may contribute to a tendency for gas production in the rumen when herbage is consumed by sheep or cattle is also reported in this volume [34]. It was hypothesised that varietal differences in sugar accumulation in herbage in winter would influence the tendency for rumen gas production, with sugar-accumulating varieties predisposing animals to bloat without providing any substantive increase in forage nutritive value. The subsequent research investigating the behaviour of varieties with lower and higher plant sugar accumulation at low temperatures confirmed key points of the hypothesis, in addition to adding new insights. First, varietal differences in total soluble carbohydrates at low temperatures were of the order of $20 \%$, whereas the sugar content of both varieties grown at $5{ }^{\circ} \mathrm{C}$ was approximately double the sugar content of the same varieties grown at $25^{\circ} \mathrm{C}$, so the temperature effect on in vitro rumen gas production was only partially mitigated in the variety with low sugar accumulation. Second, the hemicellulose content was increased in parallel with sugar accumulation at low temperatures and, as predicted, low temperatures did not significantly raise herbage in vitro digestibility. Lastly, transferring plants from cool to warm temperatures rapidly reversed the tendency of herbage grown in cool conditions to have high in vitro rumen gas production. The authors also attempted to separate the actions of light intensity and temperature and concluded that future experiments on rumen gas production should focus on cool temperature-induced, membrane-bound fructans [34]. In parallel 
with this finding it can be noted that in alfalfa, increased protein concentration at low temperatures has also been associated with an increased bloat risk [35].

More challenging to unravel is the way in which individual plant systems integrate at the organism level to create complex behavioural responses to a range of environmental conditions or stimuli. Two contributions to this volume provide reviews at this level [36,37]. Irving [36] notes that grasses provide roughly $50 \%$ of human energy consumption globally, either directly or indirectly as forage for meat production. Carbon fixation is seen as a prime driver of plant growth. He provides a functional framework for understanding the grass plant in terms of a two-pool model (shoots and roots) with $\mathrm{C}$ and $\mathrm{N}$ status in each pool influencing its volume [38], noting that the root:shoot ratio typically falls in the range of 80:20-85:15. He invokes a range of considerations to understand aspects of the internal equilibria governing plant function, including the inefficiency of Rubisco as a vehicle for $\mathrm{CO}_{2}$ capture and its capacity to fix oxygen via photorespiration. A practical outcome of this reality is that leaves require comparatively more $\mathrm{N}$ from roots to make sufficient Rubisco. He notes that $\mathrm{C}_{4}$ plants use Rubisco more efficiently by concentrating $\mathrm{CO}_{2}$ around it, but as a consequence have lower protein contents than $\mathrm{C}_{3}$ plants. He also notes in passing that one byproduct of photorespiration is malate, which provides a plant with reducing power for the assimilation of nitrate, so that drought-stressed plants with lowered leaf intercellular $\mathrm{CO}_{2}$ concentration may be comparatively more able to utilise nitrate- $\mathrm{N}$ than well-hydrated plants. Another outcome is that $\mathrm{C}$ and $\mathrm{N}$ cycles within the plant differ greatly, with some $50 \%$ of $\mathrm{C}$ incorporated in new tissues having been photosynthesised within the previous $24 \mathrm{~h}$, but less than $20 \%$ of newly incorporated $\mathrm{N}$ being recently acquired. $\mathrm{N}$ is recycled within the plant from senescing leaves for redeposition in new tissues; leaves transition from a high light environment at the top of the canopy to a low light environment lower in the canopy as they age. The leaf Rubisco formation and degradation cycle is not necessarily synchronised with the cycle of change in the light environment, but the system would be theoretically more efficient if the two cycles were synchronised. Discussion then turns to leaf area index, light capture, and assimilate allocation within the plant. Despite studies establishing that the red:far-red light ratio at the tiller base operates as a switching mechanism for tiller initiation, as well as the existence of a $-4 / 3$ allometric relationship between mean shoot dry mass and mean shoot density, knowledge of interactions between shoots, of the extent and circumstances of sharing or competition for $\mathrm{N}$ and $\mathrm{C}$, and of the principles that determine allocation to various categories of root remains rudimentary [36].

In the final contribution to this volume, Gastal and Lemaire [37] discuss sward dynamics in more detail, elucidating many of the component processes. Optimum sward leaf area index (LAI) is 3-5 with productivity inhibited by reduced light capture at $\mathrm{LAI}<3$, and by respiration of shaded leaves at LAI $>5$. Defoliation and defoliation responses are an integral part of the dynamics of grazed swards. Components or component processes contributing to or modifying LAI recovery after defoliation include shoot density, leaf elongation rate (LER), leaf appearance rate (LAR, or its reciprocal leaf elongation duration), leaf area ratio (also known as specific leaf area, SLA), and live leaf number per tiller. These entities interact in three ways: mathematically (for example, the ratio of LER:LAR is the final leaf length (FLL)), through competitively mediated mutual influences, and morphologically (because FLL is influenced in some way by the length of the pseudostem tube through which the leaf emerges) [38]. Perception of both the red:far red and blue light signals by plant receptors contributes to these responses. Thus, in the early stages of regrowth following defoliation where LAI recovery is a priority, the pattern of responses includes (relative to later in the regrowth cycle) an increase in SLA and leaf elongation duration, together with decreased LER, and FLL [38]. C availability post-defoliation is seriously limited for only a short period following defoliation [39], and either C or $\mathrm{N}$ availability may be more limiting depending on growth conditions, but recovery from repeated defoliation can be more problematic [38]. The defoliation response is not confined to changes in shoot morphology. Post-defoliation recovery of LAI is assisted by the recruitment of new tillers into the population in early regrowth, but these tillers are ephemeral and die from shading in later stages of regrowth. However, LAI recovery mechanisms in tropical grass swards with higher final LAI values and larger shoot size 
may well differ from the process described here from studies of temperate grasses. The question of the level of utilisation by grazing animals of herbage grown is neatly resolved from first principles. From a harvest efficiency perspective, optimal grazing systems will harvest about $75 \%$ of the length of each leaf produced, though a caveat is that higher harvest efficiency may compromise the maintenance of soil carbon through leaf litter return. Theoretical consideration shows that continuously stocked and rotationally grazed swards will have similar efficiency of herbage utilisation when growth conditions are favourable (i.e., growth is adequate to meet animal demand). However, when growth is limited, continuously grazed systems need to be destocked and defoliation frequency of individual shoots is not maintained. In rotational grazing systems, so long as the defoliation interval is less than one leaf life span, the defoliation intensity can be determined by the grazing pressure applied by the farmer, and utilisation efficiency will be maintained.

\section{Conclusions}

This volume provides only a snapshot of the recent research conducted across the field of forage plant ecophysiology; still, many of the world's major forage crops and major agricultural regions are represented. Those familiar with the field will recognise the consolidation of knowledge compared with similar research a generation ago. It is hoped that this will be a useful reference volume in its field for a decade to come. At the same time, it is salutary that a number of authors have commented on how little is known about some quite basic facets of plant form and function. Those knowledge gaps identified here point to advances that can be expected in the next 25 years. In an era where science is beginning to read and edit genetic code with almost the facility with which we would have read Fortran 40 years ago, it is truly surprising how much we still do not know. Considering the escalating human population pressure on the global environment, it is clear that the discipline of forage plant ecophysiology has yet to see its full development. Those early career workers in this field have an exciting and satisfying life journey ahead.

Acknowledgments: We thank Silvia Assuero, Philippe Barre, Jorge F.S. Ferreira, and Jennifer MacAdam and Sila da Silva for helpful editorial input.

Conflicts of Interest: The authors declare no conflicts of interest.

\section{References}

1. Luttge, U.; Scarano, F.R. Ecophysiology. Rev. Bras. Bot. 2004, 27, 1-10. [CrossRef]

2. English Oxford Living Dictionaries. Ecophysiology. Available online: https:/ /en.oxforddictionaries.com/ definition/us/ecophysiology (accessed on 13 March 2017).

3. Chauvin, R. Physiologie de L'insecte. Le Comportement, les Grandes Fonctions, Écophysiologie/Physiology of Insects. Behaviour, Important Functions, Ecophysiology; Institut National de la Recherche Agronomique: Paris, France, 1956.

4. Unité de Recherche Pluridisciplinaire Prairies et Plantes Fourragères. History. Available online: https: / / www6.poitou-charentes.inra.fr/urp3f/Presentation-de-l-unite/Historique (accessed on 13 March 2017).

5. Ainsworth, E.A.; Bernacchi, C.J.; Dohleman, F.G. Focus on Ecophysiology. Plant Physiol. 2016, 172, 619-621. [CrossRef] [PubMed]

6. Niklas, K.J.; Kutschera, U. The evolutionary development of plant body plans. Funct. Plant Biol. 2009, 36, 682-695. [CrossRef]

7. Ferreira, J.F.S.; Cornacchione, M.V.; Liu, X.; Suarez, D.L. Nutrient composition, forage parameters, and antioxidant capacity of alfalfa (Medicago sativa, L.) in response to saline irrigation water. Agriculture 2015, 5, 577-597. [CrossRef]

8. Marshall, A.H.; Lowe, M.; Collins, R.P. Variation in response to moisture stress of young plants of interspecific hybrids between white clover (T. repens L.) and caucasian clover (T. ambiguum M. Bieb.). Agriculture 2015, 5, 353-366. [CrossRef]

9. Williams, W.M.; Ellison, N.W.; Ansari, H.A.; Verry, I.M.; Hussain, S.W. Experimental evidence for the ancestry of allotetraploid Trifolium repens and creation of synthetic forms with value for plant breeding. BMC Plant Biol. 2012, 12, 55. [CrossRef] [PubMed] 
10. MacAdam, J.W.; Villalba, J.J. Beneficial effects of temperate forage legumes that contain condensed tannins. Agriculture 2015, 5, 475-491. [CrossRef]

11. Li, G.D.; Kemp, P.D. Forage chicory (Cichorium intybus L.): A review of its agronomy and animal production. In Advances in Agronomy, 1st ed.; Sparks, D., Ed.; Elsevier Academic Press: London, UK, 2005; Volume 88, pp. 187-222. [CrossRef]

12. Cranston, L.M.; Kenyon, P.R.; Morris, S.T.; Lopez-Villalobos, N.; Kemp, P.D. Morphological and physiological responses of plantain (Plantago lanceolata) and chicory (Cichorium intybus) to water stress and defoliation frequency. J. Agron. Crop Sci. 2016, 202, 13-24. [CrossRef]

13. Navarrete, S.; Kemp, P.D.; Pain, S.J.; Back, P.J. Bioactive compounds, aucubin and acteoside, in plantain (Plantago lanceolata L.) and their effect on in vitro rumen fermentation. Anim. Feed Sci. Technol. 2016, 222, 158-167. [CrossRef]

14. Somasiri, S.C.; Kenyon, P.R.; Kemp, P.D.; Morel, P.C.H.; Morris, S.T. Mixtures of clovers with plantain and chicory improve lamb production performance compared to a ryegrass-white clover sward in the late spring and early summer period. Grass Forage Sci. 2015, 71, 270-280. [CrossRef]

15. Matthew, C.; Mackay, A.D.; Robin, A.H.K. Do phytomer turnover models of plant morphology describe perennial ryegrass root data from field swards? Agriculture 2016, 6, 28. [CrossRef]

16. Jones, M.B.; Lazenby, B. The Grass Crop: The Physiological Basis of Production, 1st ed.; Chapman and Hall: New York, NY, USA, 1988.

17. Fulkerson, W.J.; Donaghy, D.J. Plant soluble carbohydrate reserves and senescence-Key criteria for developing an effective grazing management system for ryegrass based pastures: A review. Aust. J. Exp. Agric. 2001, 41, 261-275. [CrossRef]

18. Matthew, C.; Yang, J.Z.; Potter, J.F. Determination of tiller and root appearance in perennial ryegrass (Lolium perenne) swards by observation of the tiller axis, and potential application in mechanistic modelling. N. Z. J. Agric. Res. 1998, 41, 1-10. [CrossRef]

19. Troughton, A. Production of root axes and leaf elongation in perennial ryegrass in relation to dryness of the upper soil layer. J. Agric. Sci. 1980, 95, 533-538. [CrossRef]

20. Bryant, R.H.; Matthew, C.; Hodgson, J. Growth strategy of rhizomatous and non-rhizomatous tall fescue populations in response to defoliation. Agriculture 2015, 5, 791-805. [CrossRef]

21. Boval, M.; Dixon, R.M. The importance of grasslands for animal production and other functions: A review on management and methodological progress in the tropics. Animal 2012, 6, 748-762. [CrossRef] [PubMed]

22. Lemaire, G.; Da Silva, S.C.; Agnusdei, M.; Wade, M.; Hodgson, J. Interactions between leaf lifespan and defoliation frequency in temperate and tropical pastures: A review. Grass Forage Sci. 2009, 64, 341-353. [CrossRef]

23. Briske, D.D.; Boutton, T.W.; Wang, Z. Contribution of flexible allocation priorities to herbivory tolerance in C4 perennial grasses: An evaluation with 13C labeling. Oecologia 1996, 105, 151-159. [CrossRef] [PubMed]

24. Pinto, J.C.; Gomide, J.A.; Maestri, M. Produção de matéria seca e relação folha/caule de gramíneas forrageiras tropicais, cultivadas em vasos, com duas doses de nitrogênio. Rev. Bras. Zootec. 1994, 23, 313-326. (In Portuguese)

25. Da Silva, S.C.; Sbrissia, A.F.; Pereira, L.E.T. Ecophysiology of $\mathrm{C}_{4}$ forage grasses-Understanding plant growth for optimising their use and management. Agriculture 2015, 5, 598-625. [CrossRef]

26. Matthew, C.; Lemaire, G.; Sackville Hamilton, N.R.; Hernandez-Garay, A. A modified self-thinning equation to describe size/density relationships for defoliated swards. Ann. Bot. 1995, 76, 579-587. [CrossRef]

27. García, S.C.; Islam, M.R.; Clark, C.E.F.; Martin, P.M. Kikuyu-based pasture for dairy production: A review. Crop Pasture Sci. 2014, 65, 787-797. [CrossRef]

28. Yoda, K.; Kira, T.; Ogawa, H.; Hozumi, H. Self-thinning inovercrowded pure stands under cultivated and natural conditions. J. Biol. Osaka City Univ. 1963, 14, 107-129.

29. Hirata, M. Linking management, environment and morphogenetic and structural components of a sward for simulating tiller density dynamics in Bahiagrass (Paspalum notatum). Agriculture 2015, 5, 330-343. [CrossRef]

30. Barre, P.; Turner, L.B.; Escobar-Gutiérrez, A.J. Leaf length variation in perennial forage grasses. Agriculture 2015, 5, 682-696. [CrossRef]

31. Chapman, D.F. Using ecophysiology to improve farm efficiency: Application in temperate dairy grazing systems. Agriculture 2016, 6, 17. [CrossRef]

32. Zheng, W.; Zhang, H.X.; Japhet, W.; Zhou, D. Phenotypic plasticity of hypocotyl is an emergence strategy for species with different seed size in response to light and burial depth. J. Food Agric. Environ. 2011, 9, 742-747. 
33. Zhang, H.; Tian, Y.; Zhou, D. A modified thermal time model quantifying germination response to temperature for $\mathrm{C}_{3}$ and $\mathrm{C}_{4}$ species in temperate grassland. Agriculture 2015, 5, 412-426. [CrossRef]

34. Lorenzo, M.; Assuero, S.G.; Tognetti, J.A. Temperature Impact on the Forage Quality of Two Wheat Cultivars with Contrasting Capacity to Accumulate Sugars. Agriculture 2015, 5, 649-667. [CrossRef]

35. MacAdam, J.W.; Whitesides, R.E. Growth at low temperatures increases alfalfa leaf cell constituents related to pasture bloat. Crop Sci. 1996, 36, 378-382. [CrossRef]

36. Irving, L.J. Carbon Assimilation, Biomass Partitioning and Productivity in Grasses. Agriculture 2015, 5, 1116-1134. [CrossRef]

37. Gastal, F.; Lemaire, G. Defoliation, Shoot Plasticity, Sward Structure and Herbage Utilization in Pasture: Review of the Underlying Ecophysiological Processes. Agriculture 2015, 5, 1146-1171. [CrossRef]

38. Thornley, J.H.M. A balanced quantitative model for root: Shoot ratios in vegetative plants. Ann. Bot. 1972, 36, 431-441. [CrossRef]

39. Schnyder, H.; Nelson, C.J. Growth rates and assimilate partitioning in the elongation zone of tall fescue leaf blades at high and low irradiance. Plant Physiol. 1989, 90, 1201-1206. [CrossRef] [PubMed]

(C) 2017 by the authors. Licensee MDPI, Basel, Switzerland. This article is an open access article distributed under the terms and conditions of the Creative Commons Attribution (CC BY) license (http://creativecommons.org/licenses/by/4.0/). 